\title{
New insights into the biology of Calanus spp. (Copepoda) males in the Arctic
}

\author{
Malin Daase ${ }^{1, *}$, Ksenia Kosobokova ${ }^{2}$, Kim S. Last ${ }^{3}$, Jonathan H. Cohen ${ }^{4}$, \\ Marvin Choquet ${ }^{5}$, Maja Hatlebakk ${ }^{6}$, Janne E. Søreide ${ }^{6}$ \\ ${ }^{1}$ UiT The Arctic University of Norway, 9037 Tromsø, Norway \\ ${ }^{2}$ Institute of Oceanology, Russian Academy of Sciences, 117997 Moscow, Russia \\ ${ }^{3}$ Scottish Association for Marine Science, Scottish Marine Institute, Oban, PA371QA, UK \\ ${ }^{4}$ University of Delaware, School of Marine Science \& Policy, Lewes, Delaware 19958, USA \\ ${ }^{5}$ Faculty of Biosciences and Aquaculture, Nord University, 8049 Bodø, Norway \\ ${ }^{6}$ The University Centre in Svalbard, 9171 Longyearbyen, Norway
}

\begin{abstract}
Adult males of Calanus copepods in the Arctic are mainly observed between late autumn and late spring, and are seldom recorded during summer. Due to logistical constraints, there are still relatively few studies on zooplankton in high-latitude regions during the winter, and subsequently, little is known about Calanus males. Here, we present data on abundance, spatial distribution, prosome length, lipid content, respiration and swimming activity of Calanus adults, along with adult sex ratios in Calanus populations from 5 Arctic fjords in Svalbard, Norway $\left(78-80^{\circ} \mathrm{N}\right)$ during the polar night in January 2015, 2016 and 2017. Adult males and females of Calanus were observed at all locations and occurred throughout the entire water column. Morphological examination and molecular identification of Calanus males proved that all males encountered belong to Calanus glacialis, even in the fjords where overwintering copepodite stage CV of $C$. finmarchicus dominated at the time. Adult sex ratios in C. glacialis populations varied from 1 male per 4 females to 2 males per female. From 3 to $18 \%$ of females carried spermatophores attached to the genital segment. Lipid content in males was slightly higher than in females. Shipboard experiments showed that males had higher swimming activity and respiration rates than females. Our observations indicate that adult males of C. glacialis stay active and demonstrate active mating behavior in mid-winter, and that the mating phenology of C. glacialis is decoupled from that of $C$. finmarchicus in the study area in January.
\end{abstract}

KEY WORDS: Calanus glacialis $\cdot$ Polar night $\cdot$ Svalbard $\cdot$ Mating $\cdot$ Sex ratio $\cdot$ Metabolism

\section{INTRODUCTION}

Calanoid copepods of the genus Calanus dominate the mesozooplankton communities of Arctic and sub-Arctic seas in terms of biomass (Kosobokova \& Hirche 2009). They play a major role in the Arctic marine ecosystem, converting their algal diet into energy-rich lipid storages and thus facilitating the transfer of energy from primary production to higher trophic level organisms such as fishes, sea birds and marine mammals (Falk-Petersen et al. 2009). Due to their importance in the marine ecosystem, Calanus species are probably the most studied copepod taxa,

\footnotetext{
*Corresponding author: malin.daase@uit.no
}

not only in the Arctic but also in sub-Arctic and boreal seas. A number of publications have described the spatial distribution of Calanus species in these regions (e.g. Conover 1988, Hirche \& Kosobokova 2007, Falk-Petersen et al. 2009, Wassmann et al. 2015, Choquet et al. 2017) and there is a good understanding of different aspects of their life history such as timing of reproduction (Niehoff et al. 2002, Søreide et al. 2010, Daase et al. 2013), vertical migration, juvenile development, and energy requirements for reproduction and growth (e.g. Niehoff 2004, Søreide et al. 2008, 2010, Falk-Petersen et al. 2009).

(C) The authors 2018. Open Access under Creative Commons by Attribution Licence. Use, distribution and reproduction are unrestricted. Authors and original publication must be credited. 
Three species of Calanus co-occur in the Atlanticinfluenced part of the Arctic Ocean: the North Atlantic species $C$. finmarchicus, the arctic shelf species C. glacialis and the arctic oceanic species $C$. hyperboreus (Conover 1988, Choquet et al. 2017). The basic life cycle of Calanus species in Arctic and Sub-Arctic seas includes a seasonal migration, with the main developmental and growth phase occurring near the surface during spring and summer and an overwintering phase at depth with reduced metabolism (diapause) in winter (Falk-Petersen et al. 2009). The final developmental step towards adulthood takes place sometime between late autumn and spring, with the largest and most lipid-rich CVs moulting to adults first, and males appearing before females (Østvedt 1955, Kosobokova 1999, Bailey 2010). The 3 Calanus species have tuned their life-history strategies in relation to the timing and predictability of the spring bloom, ice cover and other factors in their main area of distribution (Falk-Petersen et al. 2009). C. finmarchicus is advected to the Arctic mainly with Atlantic water currents. In the northernmost part of its distribution range, C. finmarchicus has a 1 yr life cycle and relies on external energy supplied by the spring bloom to fuel reproduction (i.e. income breeding). The ability of $C$. finmarchicus to survive and colonize the Arctic Ocean, however, is hampered by short algae growing seasons and low temperatures (Jaschnov 1970, Tande et al. 1985, Ji et al. 2012), and hence the species largely fails to reproduce in the Arctic Ocean and surrounding shelf seas (Hirche et al. 2006). The larger C. glacialis is very productive along the entire shelf break and surrounding shelf seas of the Arctic (Kosobokova \& Hirche 2001, Ashjian et al. 2003, Hirche \& Kosobokova 2003). C. glacialis has a 1-2 yr life cycle (Kosobokova 1999, Søreide et al. 2010, Daase et al. 2013) and is efficient at utilizing the 2 available food sources in seasonal ice-covered seas (ice algae and phytoplankton) for reproduction and growth. The early ice algae bloom is primarily utilized to fuel gonad maturation and egg production (income breeding) while the later phytoplankton bloom supports growth and development of its new generation (Hirche 1989, Tourangeau \& Runge 1991, Søreide et al. 2010, Wold et al. 2011). However, egg production can also occur before any algal food is present, being fuelled by internal resources only (i.e. capital breeding). The flexible reproductive strategies observed in C. glacialis may explain its wide distribution in seasonally ice-covered Arctic shelf seas (Daase et al. 2013), a region of high inter-annual variability in the timing of ice break-up and bloom phenology. The largest of the 3 species, $C$. hyperboreus, has its centre of distribution in the Greenland Sea and the Central Arctic Ocean, and is specialized to the highly unpredictable timing of the spring bloom in the Arctic Ocean. It is a pure capital breeder, producing eggs at depth in winter decoupled from the spring bloom (Hirche \& Niehoff 1996, Hirche 2013).

Given the key role of Calanus spp. in the food web, discussions of their fate in a warming Arctic has become a research priority in recent years (e.g. Ji et al. 2012, Kjellerup et al. 2012, Kwasniewski et al. 2012, Grote et al. 2015, Wilson et al. 2016). However, winter studies are still scarce and knowledge on Calanus males and their biology is basically nonexistent from the Arctic, hindering a thorough understanding of Calanus life-history strategies needed to assess their response to Arctic warming.

Calanus males seem to have a rather short life span, similar to males of many other copepod species (Bogorov 1939, Mednikov 1961). Kosobokova (1999) reported that males of C. glacialis have only a 3-4 mo life span in the White Sea, and Marshall \& Orr (1955) suggested that the life span of $C$. finmarchicus males does not exceed 7 mo even at high latitudes. In comparison, the life span of females of C. glacialis may vary from 9-10 mo up to $1.5 \mathrm{yr}$, and it has been suggested that C. glacialis females may even be iteroparous (Kosobokova 1999).

The absence of C. glacialis males is noteworthy during the period of most active biological sampling from late spring to autumn (e.g. Kosobokova 1999, Ashjian et al. 2003, Darnis \& Fortier 2014), while females are found year-round (e.g. Kosobokova 1999, Wold et al. 2011, Daase et al. 2013). Males start to appear in northern polar waters in early autumn and can persist until May-June, with most studies observing maximum abundance and highest proportion of $C$. glacialis males between December and February (Madsen et al. 2001, Niehoff et al. 2002, Wold et al. 2011, Estrada et al. 2012, Darnis \& Fortier 2014). Periods of peak abundance thus coincide with the polar night, a period that is traditionally understudied due to logistical constraints of conducting fieldwork at high latitudes in darkness, extreme low temperatures and in often ice-covered seas. As a result, male abundance, size range and structure, feeding habits, metabolic rates and lipid content have been poorly documented, and their life span remains uncertain.

Here, in order to fill knowledge gaps on Calanus spp. reproductive strategies due to the lack of data on males, we collected zooplankton samples in the middle of winter in the Arctic archipelago of Svalbard, during the supposed peak of Calanus male abun- 
dance (Bailey 2010). Although it is likely that males of all 3 Calanus species are present in the studied area, we focused only on $C$. finmarchicus and $C$. glacialis since abundance of $C$. hyperboreus is generally low in the fjords and on the shelf (Daase \& Eiane 2007, Blachowiak-Samolyk et al. 2008, Søreide et al. 2008). The vertical distribution, abundance, morphology, activity and physiology of Calanus spp. adults were investigated together with the females' gonad maturation state in order to understand and document for the first time the details of the mating phase of Calanus spp. in the Arctic.

\section{MATERIALS AND METHODS}

\section{Study area}

Zooplankton samples were collected in January 2015, 2016 and 2017 in fjords along the western and northern coast of the Svalbard archipelago (Fig. 1, Table S1 in the Supplement at www.int-res.com/ articles/suppl/m607p053_supp.pdf) onboard the R/V 'Helmer Hanssen'. In January 2015, samples were collected at 3 stations in Kongsfjorden: the outer (KF1), the middle (KF3) and the innermost part of the fjord close to the glacier front (KF5). In January 2016, samples were collected in Kongsfjorden (KF3 and KF5), Isfjorden (IF), Billefjorden (BF), Smeerenburgfjorden (SMF) and Rijpfjorden (RF), and in January 2017, sampling was repeated at IF, KF3, SMF and RF (Fig. 1, Table S1).

Isfjorden, Kongsfjorden and Smeerenburgfjorden are located on the western coast of Svalbard and may be affected by inflow of Atlantic water from the West Spitsbergen Current (Cottier et al. 2005, Nilsen et al. 2008). Billefjorden is a sill fjord in the inner part of Isfjorden and is largely unaffected by inflowing Atlantic water but dominated by locally formed cold water (less than $-0.5^{\circ} \mathrm{C}$ year-round), providing a refuge for Arctic zooplankton species (Arnkværn et al. 2005). Rijpfjorden is a north-facing fjord dominated by cold Arctic water masses, but inflow of Atlantic water may occur (Wallace et al. 2010). All fjords were ice-free during our study in January 2015, 2016 and 2017.

\section{Hydrography}

Measurements of temperature and salinity were obtained at all stations by a ship-board conductivity, temperature and depth profiler (SBE911plus, SeaBird Electronics).

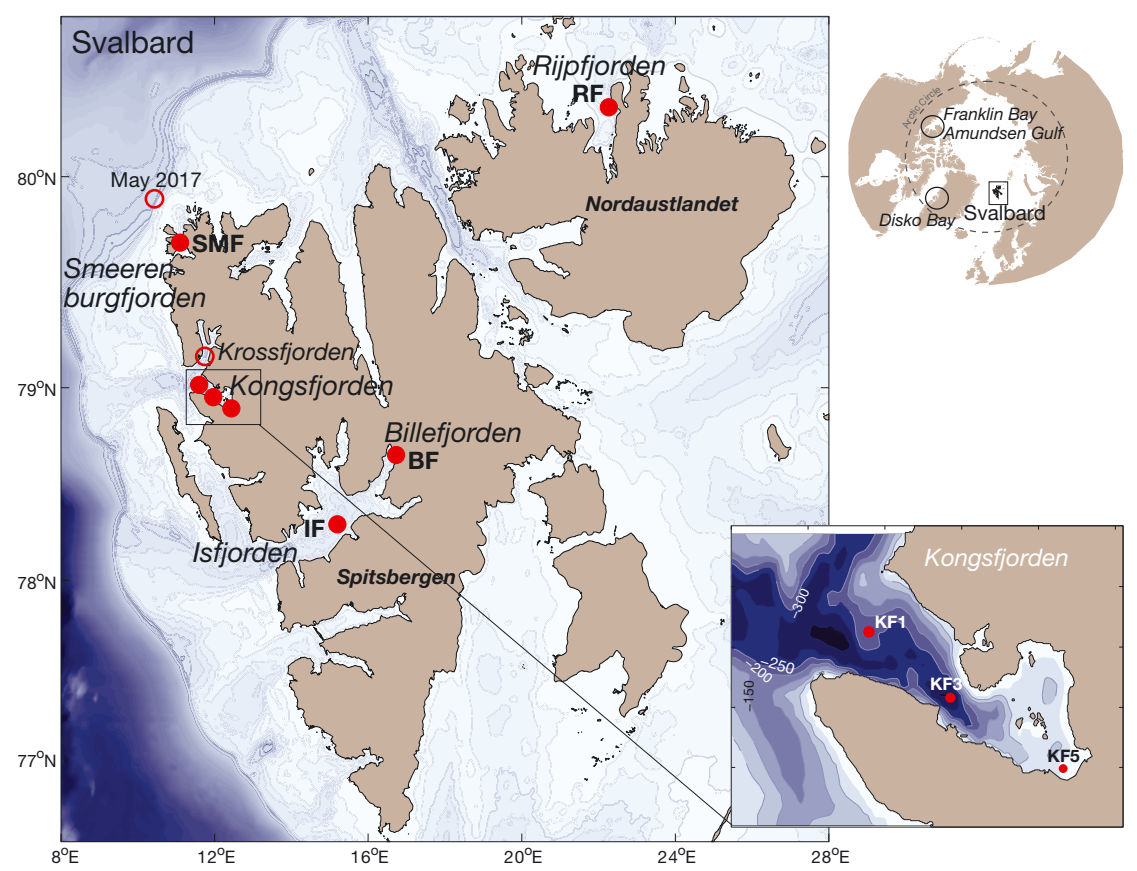

Fig. 1 Map of study area. Red dots show location of main sampling sites in Svalbard fjords. Red circles indicate sampling sites where additional samples were taken. Inset in lower right corner shows locations of stations sampled in Kongsfjorden. Arctic map in upper right corner shows location of Svalbard as well as locations of sampling sites referred to in Fig. 9

\section{Zooplankton abundance and vertical distribution}

Zooplankton were sampled by vertical net hauls (towing speed $0.5 \mathrm{~m}$ $\mathrm{s}^{-1}$ ) from close $(10-20 \mathrm{~m})$ to the seafloor up to the surface using a multiple opening/closing net (Multinet; Hydrobios: mouth opening $0.25 \mathrm{~m}^{2}$, mesh size $180 \mu \mathrm{m})$. Up to 5 depth strata were sampled at each location (Table S1). Samples were preserved in a $4 \%$ hexamethylenetetraminebuffered formaldehyde-in-seawater solution and analyzed under a Leica stereomicroscope at institutional home laboratories. Samples were examined by subsampling with aliquots obtained by $5 \mathrm{ml}$ automatic pipette, with the pipette tip cut at $5 \mathrm{~mm}$ diameter to allow free collection of mesozooplankton. Prior to taking subsamples, large (total length $>5 \mathrm{~mm}$ ) organisms were picked out using forceps. The 
number of subsamples analyzed was chosen so that at least 150 individuals of Calanus copepodites were counted. Samples with low abundances were examined in their entirety. Adult males (AM) and females (AF) of Calanus were counted from the entire samples. The prosome length of all counted individuals of Calanus spp. was measured from the tip of cephalosome to the distal lateral end of the last thoracic segment with precision of $\pm 50 \mu \mathrm{m}$.

\section{Calanus species identification}

To distinguish between the morphologically similar C. glacialis and C. finmarchicus from formalin-preserved samples, we used size classes derived for each developmental stage (copepodites CIII-CVI) from prosome length frequency analyses for the study region (Daase \& Eiane 2007) (Table 1), which were readjusted after considering molecular-based studies (Gabrielsen et al. 2012, Choquet et al. 2018, Renaud et al. 2018). These molecular investigations have indicated a much higher overlap in prosome length between the 2 species than previously assumed, resulting in a regionally variable potential for misidentification. In our study area, misidentifications based on size classes seemed, for the most part, to be unidirectional (Gabrielsen et al. 2012, Choquet et al. 2018) and biased towards an underestimation of $C$. glacialis and a comparative overestimation of C. finmarchicus. Since prosome length measurements of genetically identified Calanus CV and females indicate a discrepancy between previously published size classes for the study area (e.g. Daase \& Eiane 2007, Kwasniewski et al. 2003) and observed prosome length (Gabrielsen et al. 2012, Renaud et al. 2018), we adjusted the size classes and defined $\mathrm{CV} \geq$ $2.9 \mathrm{~mm}$ and $\mathrm{AF} \geq 2.95 \mathrm{~mm}$ as $C$. glacialis (Table 1 ).

In living Calanus, the presence or absence of red pigmentation of the antennules has been genetically

Table 1. Size ranges (prosome length, $\mathrm{mm}$ ) used to differentiate between copepodite stages CIII-CV and adult females (AF) of Calanus finmarchicus and C. glacialis based on Daase \& Eiane (2007). Size classes for CV and AF have been readjusted based on molecular identification (Gabrielsen et al. 2012, Renaud et al. 2018)

\begin{tabular}{|lcr|}
\hline & C. finmarchicus & C. glacialis \\
\hline CIII & $1.12-1.47$ & $1.47-2.07$ \\
CIV & $1.6-2.01$ & $2.01-3.63$ \\
CV & $1.92-2.9$ & $2.9-3.99$ \\
AF & $2.4-2.95$ & $2.95-4.63$ \\
\hline
\end{tabular}

confirmed as useful to distinguish between CIV, CV and $\mathrm{AF}$ of $C$. finmarchicus (pale antennules) and $C$. glacialis (antennules with red pigmentation) (Nielsen et al. 2014, Choquet et al. 2018). This characteristic was used to identify $C$. glacialis from digital images taken to estimate lipid content (see below) and when selecting AF for respiration and swimming activity measurements (see below). The pigmentation of antennules is, however, not present in AM of either species.

The morphology of the $5^{\text {th }}$ thoracic leg (swimming leg P5) can also be used to identify Calanus to species following descriptions by Jaschnov (1955), Frost (1974) and Brodskii (1967), although the method has recently been proven to be unreliable for CVs and AF (Choquet et al. 2018). For males, the morphological characteristics are more clearly defined than in females, and we used this morphological feature to identify a subset of Calanus males (those sampled in Rijpfjorden) to species as described in Choquet et al. (2018) to check the reliability of size classes derived for AM in this study.

Another subset of Calanus males was identified to species using molecular tools. A total of 80 Calanus males sampled at KF3 in January 2015 using a MIK net (mouth opening $3.14 \mathrm{~m}^{2}$, mesh size $1500 \mu \mathrm{m}$ ), and 40 males from BF and 74 males from RF sampled in January 2016 using the Multinet were preserved individually in $96 \%$ ethanol. Prosome length of each individual was measured from digital images taken prior to preservation. Individuals were genetically identified to species following procedures described in Choquet et al. (2017). To compare the size structure and species composition of Calanus males in January with that of Calanus males found in spring, we used the same methods on 42 randomly selected Calanus males collected with a WP3 net $\left(1 \mathrm{~m}^{2}\right.$ mouth opening, $1000 \mu \mathrm{m}$ mesh size) during a cruise in May 2017 north-west of Svalbard (Fig. 1, Table S1).

\section{Estimation of lipid content}

In 2015 and 2016, additional Multinet samples were taken at BF, KF3, SMF and RF from which live Calanus were sorted out to estimate the lipid content of individuals (see Table S1 for sample depth). Digital images (lateral view) of all specimens in subsamples containing at least 100 Calanus were taken following procedures described in Daase et al. (2014) using a Leica stereomicroscope with a camera Leica DFC420 or Sony HDR_HC7 video camera. Copepodite stage of each individual was determined while taking the 
pictures. The digital images were used to measure lipid sac area, prosome length and prosome area of specimens using ImageJ, an open source graphics program (Rasband 1997-2009). Lipid content of individual Calanus specimens was calculated from lipid sac area according to Vogedes et al. (2010).

The variance in lipid content and lipid sac area/ prosome area ratio (LA/PA; an indication of the fullness of the body) was not homogenous. We therefore applied the non-parametric Kruskal-Wallis test to test for differences in lipid content and LA/PA between copepodite stages, followed by the post hoc test according to Nemenyi for pairwise multiple comparisons of the ranked data. Statistical analyses were done in RStudio v.1.0.143.

\section{Gonad maturation status and spermatophore counts}

The gonad maturation stage (GS) of adult Calanus females and CVs were examined using formalinpreserved samples. A total of 30 randomly selected females and CVs from each fjord sampled in 2016 were stained with $2 \%$ borax carmine solution (Tande \& Hopkins 1981), dehydrated and stored in glycerine. The GS of females was assessed according to the classification scheme suggested by Niehoff \& Hirche (1996). Four stages of gonad maturation (GS1-GS4) were distinguished. The gonads in CVs were examined to discriminate between sexually undifferentiated specimens and potential females/males, according to Kosobokova $(1998,1999)$. The number of AF bearing spermatophores was assess in all Multinet samples collected in January 2015 and 2016.

\section{Swimming activity and respiration}

Measurements of swimming activity of Calanus AM and AF were taken using a modified LAM10 locomotor activity monitor (LAM; Trikinetics) connected to a laptop computer. The LAM monitors use infrared light beam arrays to detect the motion of animals in test chambers (2.5 ml clear acrylic tubes); beam breaks are recorded on the computer. For activity experiments, animals were collected in January 2017 in Krossfjorden (a side-fjord of Kongsfjorden; Fig. 1) and at RF using a Hydrobios WP2 net (mesh size $180 \mu \mathrm{m}$, mouth opening $0.25 \mathrm{~m}^{2}$ ), vertically hauled from $100 \mathrm{~m}$ to the surface. Net contents were immediately transferred to a shipboard temperaturecontrolled room at $4.5^{\circ} \mathrm{C}$, where sorting was undertaken by stereomicroscope under a dim red light.
Sorted animals were individually transferred into the LAM monitor tubes, each containing $\sim 2 \mathrm{ml}$ of $0.5 \mu \mathrm{m}$ filtered seawater. Animals were left undisturbed and under constant darkness in the shipboard temperature-controlled room at $4.5^{\circ} \mathrm{C}$ for $\sim 2 \mathrm{~d}$ and their activity logged, after which each copepod was photographed to confirm species and stage (see methods described above). Rayleigh's tests were used to determine whether bouts of swimming activity were clustered over the diel cycle, while rank sum tests were used to compare variance of swimming activity between AM and AF at Krossfjorden and RF.

From net collections at RF we also measured weightspecific oxygen consumption rates in individual adult C. glacialis males $(\mathrm{n}=11)$ and females $(\mathrm{n}=8)$. Respiration rates were measured in darkness at $4.5^{\circ} \mathrm{C}$ in 1 min intervals over $\sim 10 \mathrm{~h}$ using a 24 -well microplate respirometry system (Loligo Instruments). Individual copepods were tested in $200 \mu \mathrm{l}$ wells, with respiration rates calculated over an interval where partial pressures were 90-80\% air saturation in each well, ensuring measurements considered only independent respiration. Copepods were photographed following experiments, from which prosome length was calculated and used to derive dry weight (M. Daase \& J. E. Søreide unpubl. data) for correcting respiration by copepod size:

$$
\mathrm{DW}=\mathrm{e}^{2.25} \mathrm{PL}^{3.31}
$$

where DW is dry weight (mg) and PL is prosome length (mm).

Respiration rates were compared between AM and AF by a rank sum test. While both copepod activity and respiration in the experiments described above could be influenced by tank enclosure effects in these relatively small volumes, we ensured that our methods were consistent between individuals and therefore any differences are very likely due to inherent differences among sexes/sites as opposed to experimental artefacts.

\section{RESULTS}

\section{Hydrography}

Atlantic and Transformed Atlantic water prevailed in Kongsfjorden and Isfjorden during our studies (Fig. 2). The water column in Kongsfjorden was wellmixed and homogenous in 2015, and stratified, warmer and fresher in 2016 and 2017. Water masses in Isfjorden were similar to Kongsfjorden in 2016 and 2017. Cooler and fresher waters were observed in 

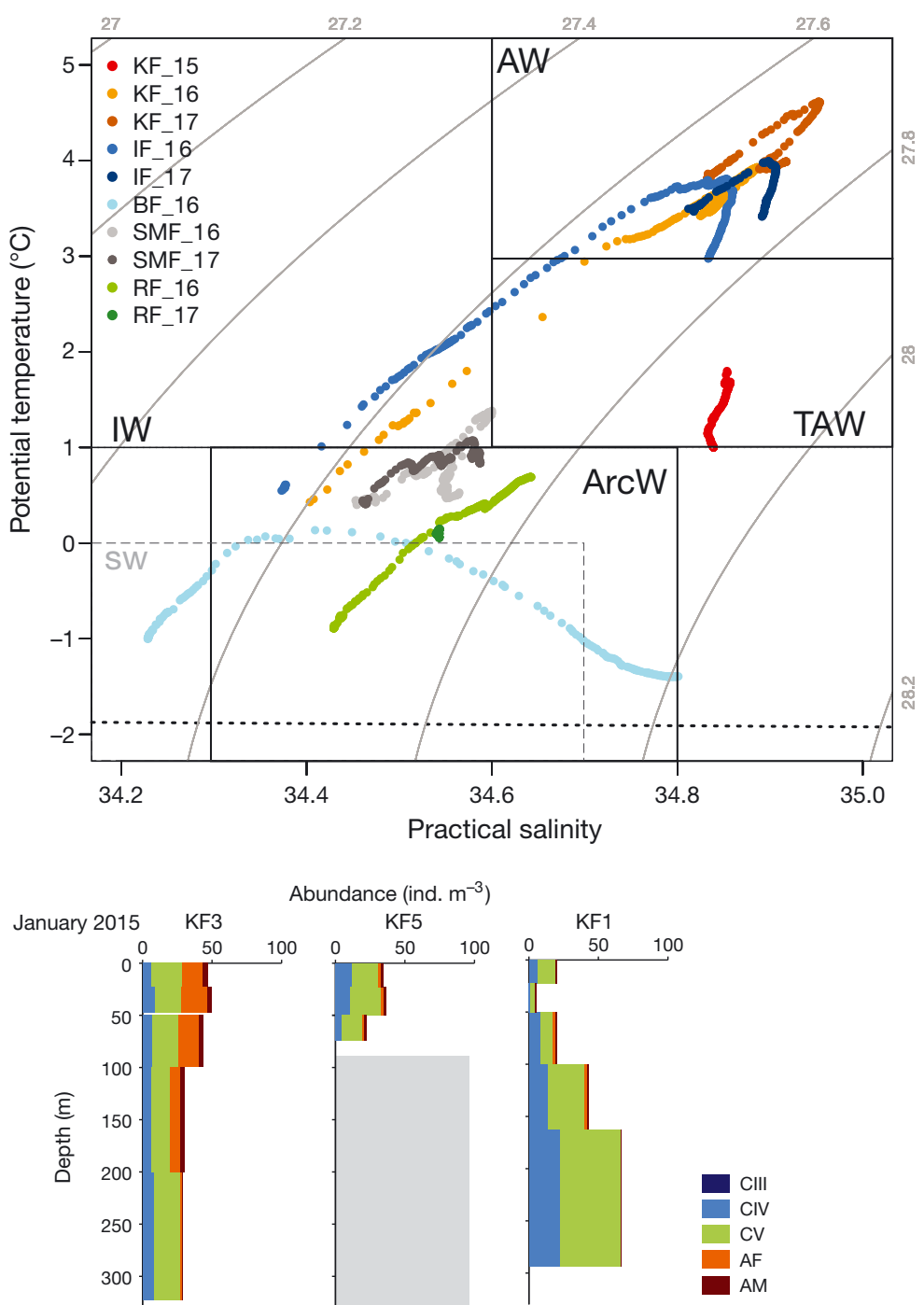

Abundance (ind. $\mathrm{m}^{-3}$ )
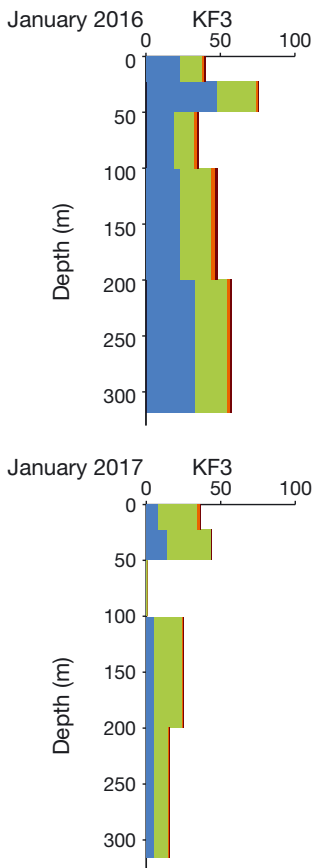
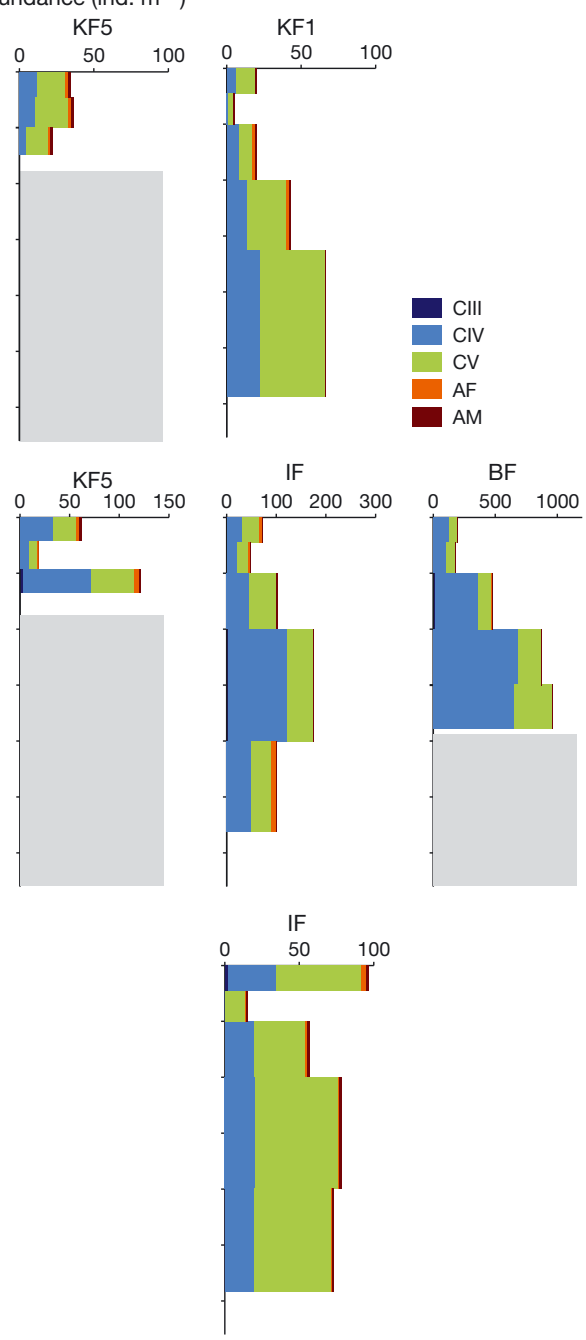

Fig. 2. TS-diagram of water masses in January in Kongsfjorden (KF3): 2015 (KF_15), 2016 (KF_16) and 2017 (KF_17); Isfjorden: 2016 (IF_16) and 2017 (IF_17); Billefjorden: 2016 (BF_16); Smeerenburgfjorden: 2016 (SMF_16) and 2017 (SMF_17); and Rijpfjorden: 2016 (RF_2016) and 2017 (RF_17). AW: Atlantic water; TAW: Transformed Atlantic water; ArcW: Arctic water; IW: intermediate water; SW: surface water (grey dashed box). Black dotted line indicates freezing point. Grey lines show isopycnals at 0.2 intervals. Water mass definitions based on Cottier et al. (2005)

Billefjorden and Rijpfjorden, indicating the presence of Arctic or locally formed water cooled during the winter. Smeerenburgfjorden was warmer than Rijpfjorden and Billefjorden, but not as warm as Kongsfjorden and Isforden.

\section{Calanus stage composition, length frequency and genetics}

Abundance of the larger and easily morphologically distinguishable Calanus hyperboreus was low in the study area (0.162.5 ind. $\mathrm{m}^{-3}$ ) and we therefore only report data on C. finmarchicus and C. glacialis, which were abundant in all fjords.

The Calanus population in January was dominated by copepodite stages CIV and CV (Fig. 3). CVs dominated at all stations in 2015
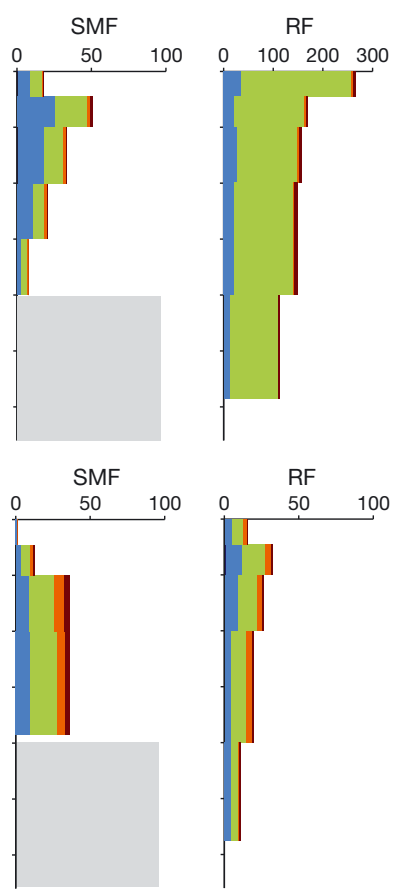

Fig. 3. Vertical distribution, stage composition and abundance of Calanus spp. in 5 Svalbard fjords. Note differences in scale of $x$-axis. Gray bars: bottom depth. AF: adult females; AM: adult males 

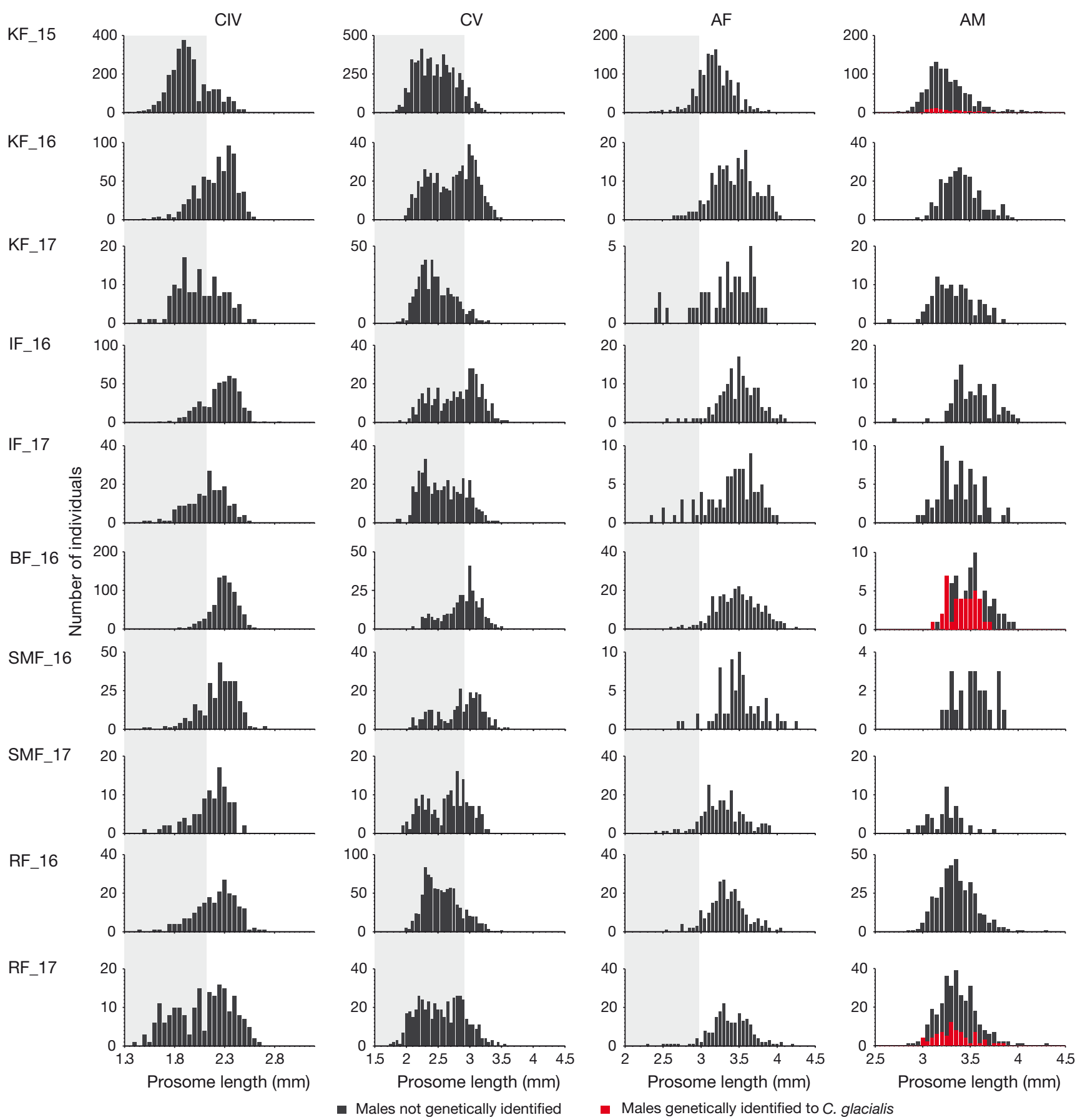

- Males genetically identified to $C$. glacialis

Fig. 4. Station-specific prosome length frequency distributions of Calanus spp. copepodite stage CIV and CV, adult females (AF), and adult males (AM) for Kongsfjorden 2015 (KF1, KF3 and KF5 pooled), 2016 (KF3 and KF5 pooled), 2017 (KF3); Isfjorden (IF) 2016, 2017; Billefjorden (BF) 2016; Smeerenburgfjorden (SMF) 2016, 2017; and Rijpfjorden (RF) 2016, 2017. Red bars for AM in KF_15, BF_16 and RF_16 show length frequency distribution of males genetically identified as C. glacialis. Gray shaded areas: size range assigned to $C$. finmarchicus (see Table 1)

and 2017, while CIVs were more abundant in 2016, except at RF. The prosome length frequency of copepodite stage IV (CIV) was biomodal but skewed towards larger individuals at almost all locations, indicating a dominance of $C$. glacialis among CIVs
(Fig. 4). Exceptions were Kongsfjorden in 2015 and 2017, where the majority of CIV fell into the size classes assigned to C. finmarchicus, and Rijpfjorden in 2017, which showed equal numbers of CIVs for both size classes. In contrast, the length distribution of 


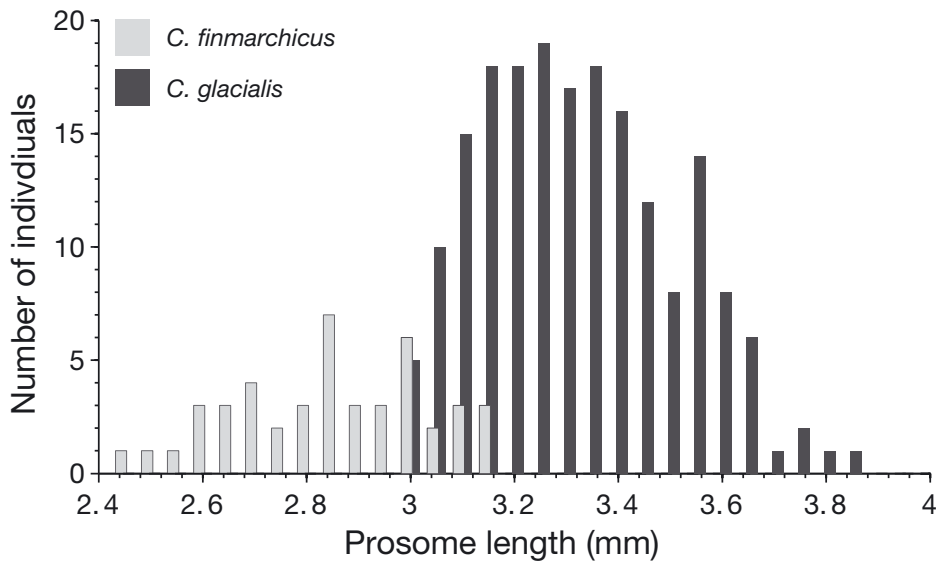

Fig. 5. Prosome length frequency distribution of genetically identified Calanus adult males (AM). C. finmarchicus AM were sampled in north-west Svalbard in May 2017, and C. glacialis AM were collected in Svalbard fjords in January 2015 and 2016 (see also Fig. 3)
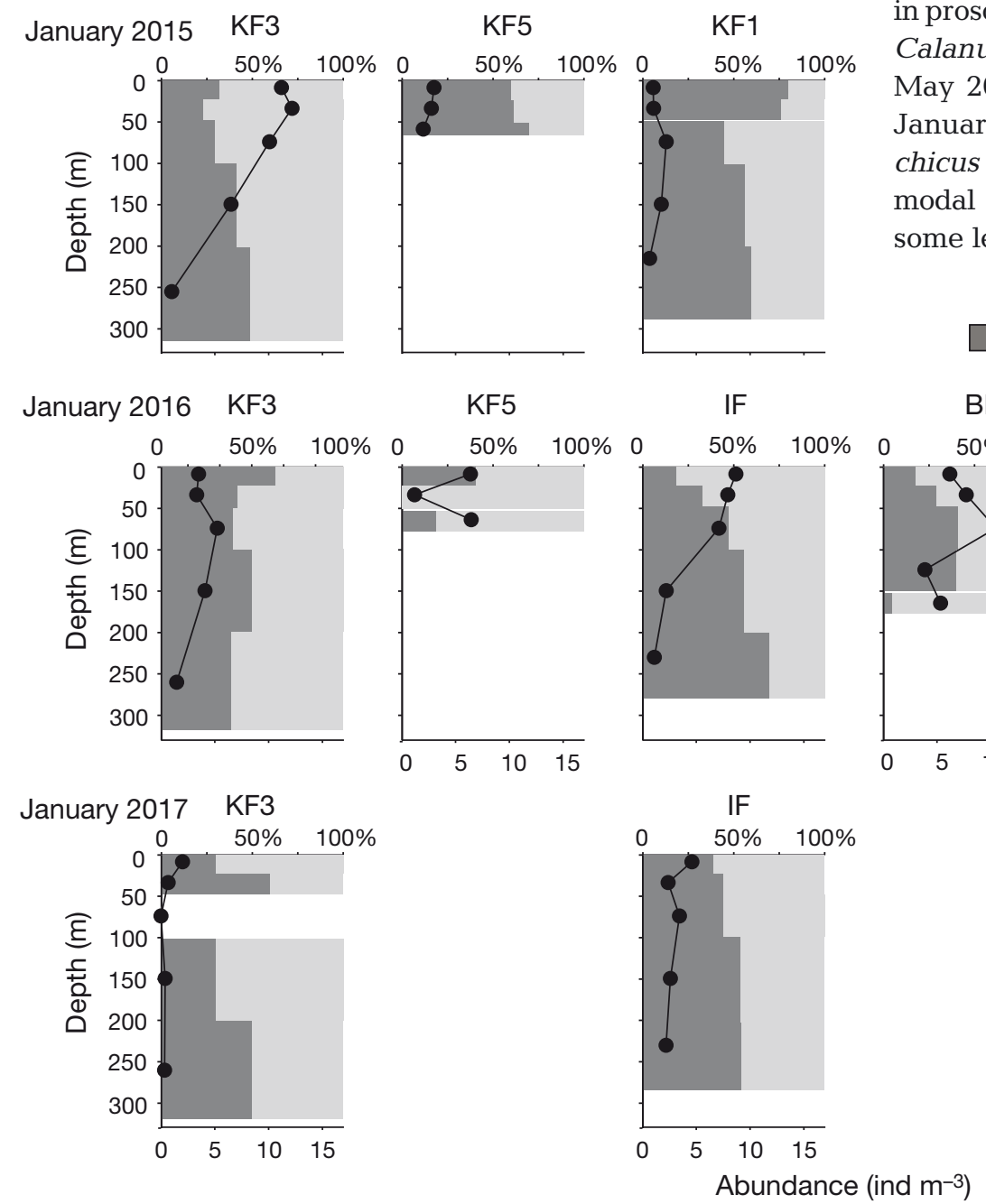

CVs was skewed towards smaller sizes, indicating a dominance of $C$. finmarchicus $\mathrm{CVs}$ at most locations (Fig. 4), with the exception of BF and SMF in 2016 (Fig. 3). The length distribution of AF was largely unimodal, with only few smaller AF present (Fig. 4). The size range and length frequency distribution pattern of AM closely resembled that of AF, but no AM smaller than 2.7 mm were observed. All 194 AM identified to species using molecular tools (corresponding to $10 \%$ of all measured males) were found to be $C$. glacialis. Prosome length of these genetically identified AMs varied from 3.00 to $3.84 \mathrm{~mm}$ and the length frequency distribution overlapped entirely with the length frequency distribution of AM not identified genetically (Fig. 4). Morphological examination of the fifth pair of swimming legs (P5) of AM from RF in 2016 indicated that only C. glacialis AM were present there, ranging in prosome length from $2.85-4.05 \mathrm{~mm}$. In contrast, Calanus AM sampled north-west of Svalbard in May 2017 were smaller than those observed in January. They were all identified as $C$. finmarchicus using molecular tools and displayed a unimodal length frequency distribution with prosome length varying from 2.40-3.14 mm (Fig. 5).

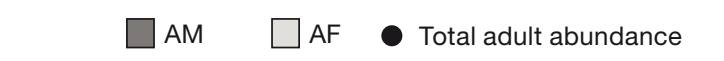

Fig. 6. Vertical distribution of Calanus glacialis adult females (AF; light gray) and males (AM; dark gray) at each station in January 2015, 2016 and 2017. Black dots: total adult abundance (ind. $\mathrm{m}^{-3}$ ) 
Table 2. Abundance of adult males (AM) and females (AF) of Calanus glacialis (ind $\mathrm{m}^{-2}$ ), and sex ratios and percentage of C. glacialis females observed with spermatophores. nd: not determined

\begin{tabular}{|lcccc|}
\hline Station & $\begin{array}{c}\text { No. AM } \\
\text { (ind. } \mathrm{m}^{-2} \text { ) }\end{array}$ & $\begin{array}{c}\text { No. AF } \\
\text { (ind. } \mathrm{m}^{-2} \text { ) }\end{array}$ & $\begin{array}{c}\text { Sex ratio adults } \\
\text { males:females }\end{array}$ & $\begin{array}{c}\text { \% AF with } \\
\text { spermatophores }\end{array}$ \\
\hline $\mathbf{2 0 1 5}$ & & & & \\
KF1 & 200 & 276 & 0.7 & 13.9 \\
KF3 & 636 & 2328 & 0.3 & 9.2 \\
KF5 & 116 & 128 & 0.9 & 17.6 \\
$\mathbf{2 0 1 6}$ & & & & \\
KF3 & 384 & 532 & 0.7 & 8.1 \\
KF5 & 68 & 176 & 0.4 & nd \\
IF & 356 & 969 & 0.4 & 9.2 \\
BF & 256 & 1048 & 0.2 & 3.3 \\
SMF & 88 & 272 & 0.3 & 8.3 \\
RF & 1240 & 784 & 1.6 & 7.3 \\
2017 & & & & nd \\
KF3 & 56 & 64 & 0.9 & nd \\
IF & 356 & 328 & 1.1 & nd \\
SMF & 484 & 784 & 0.6 & \\
RF & 260 & 608 & 0.4 & \\
\hline
\end{tabular}

\section{Calanus vertical distribution and abundance}

At almost all stations, the Calanus population was distributed throughout the entire water column (Fig. 3). Exceptions were KF1 in 2015 and BF in 2016, where the bulk of the Calanus population was concentrated in the deeper layers. Total Calanus abundances were highest in RF, BF and IF in 2016 (Fig. 3); low Calanus abundance was observed in Kongsfjorden in 2015 (Fig. 4).

Both AM and AF were distributed throughout the entire water column (Fig. 6). The highest abundance of Calanus AF was observed in KF3 in 2015 (2328 ind. $\mathrm{m}^{-2}$; Table 2), which was 2-3 times higher than maximum AF abundance recorded in 2016 and 2017. The contribution of C. glacialis AM to the total C. glacialis population was highest in 2015, at 12-25\%. In 2016 and 2017, AM contributed 2-12 and 5-11\%, respectively.

\section{Sex ratios and proportion of females with spermatophores}

The sex ratio in the $C$. glacialis population varied from 1.6 (ca. $2 \mathrm{AM} \mathrm{AF}^{-1}$ ) in $\mathrm{RF}$ in 2016 to a pronounced prevalence of AF in $\mathrm{BF}\left(0.04-0.2 \mathrm{AM} \mathrm{AF}^{-1}\right)$ and SMF (0.1-0.3 $\mathrm{AM} \mathrm{AF}^{-1}$ ) in 2016, especially in the deeper layers (Fig. 6, Table 2).

Between 3 and $18 \%$ of the Calanus AF carried spermatophores (Table 2). The highest proportion of such females was observed in Kongsfjorden in 2015 (where we also observed the highest AF abundance), and at IF in 2016. The lowest proportion of AF with spermatophores was found at BF in 2016 (Table 2). AF carrying spermatophores were not counted in 2017. Length measurements of AF with spermatophores showed that the majority fell within the size class of C. glacialis, with $18 \%$ (24 ind., most of them observed in KF in 2015) being slightly smaller (2.6-2.9 mm) but still within a size range that may include AF of C. glacialis (Renaud et al. 2018) (Fig. S1 in the Supplement). There was no relationship between the proportion of AF with spermatophores and the number of AM, AF or the sex ratio, but there was a positive correlation between the proportion of AF with spermatophores and the proportion of $C$. glacialis AM relative to the total C. glacialis abundance (Pearson correlation, $\mathrm{r}=0.811, \mathrm{p}=0.015)$.

\section{Gonad status and CV sex ratios}

We assessed the gonad stage of AF and the CV sex ratios from samples taken in 2016. The majority of both C. glacialis and C. finmarchicus AF were immature (>95\% with gonad stage GS1) (Table 3). The majority of CVs (75\%) in both species were classified as potential females except for CVs from RF and BF, where up to $50 \%$ of CV specimens still had sexually undifferentiated gonads (Table 4). Overall, only a small portion $(<5 \%)$ of CVs were developing male gonads and could be classified as potential males.

\section{Lipids}

The adults of $C$. glacialis had higher lipid content and a higher LA/PA compared to CIV and CV in January (Fig. 7). Differences in lipid content and LA/PA

Table 3. Gonad maturation stage (GS) of Calanus glacialis ( $\%$ of adult females [AF] with GS1, GS2 or undifferentiated gonads) in January 2016

\begin{tabular}{|lccc|}
\hline & GS1 & GS2 & $\begin{array}{c}\text { Undifferentiated } \\
\text { gonads }\end{array}$ \\
\hline KF3 & 99.1 & 0.9 & 0.0 \\
IF & 100.0 & 0.0 & 0.0 \\
BF & 98.1 & 0.0 & 1.9 \\
SMF & 94.0 & 1.5 & 4.5 \\
RF & 100 & 0 & 0 \\
\hline
\end{tabular}


Table 4. Gonad differentiation in Calanus glacialis and C. finmarchicus CVs in January 2016 (\% of CVs with sexually undifferentiated gonads, potential female and potential male gonads). N: number of individuals examined

\begin{tabular}{|c|c|c|c|c|c|c|c|c|c|c|}
\hline \multirow[t]{2}{*}{ Station } & \multirow[b]{2}{*}{$\mathrm{N}$} & \multirow[b]{2}{*}{$\%$ undiff. } & \multirow{2}{*}{$\begin{array}{l}\text { - C. glacialis } \\
\% \text { female }\end{array}$} & \multirow[b]{2}{*}{$\%$ male } & \multirow[b]{2}{*}{ Sex ratio } & \multirow[b]{2}{*}{$\mathrm{N}$} & \multirow[b]{2}{*}{$\%$ undiff. } & \multicolumn{2}{|c|}{ C. finmarchicus } & \multirow[b]{2}{*}{ Sex ratio } \\
\hline & & & & & & & & $\%$ female & $\%$ male & \\
\hline KF3 & 137 & 5.1 & 91.2 & 3.6 & 0.04 & 15 & 26.7 & 73.3 & 0.0 & 0.00 \\
\hline IF & 132 & 9.1 & 88.6 & 2.3 & 0.03 & 15 & 53.3 & 46.7 & 0.0 & 0.00 \\
\hline $\mathrm{BF}$ & 97 & 38.1 & 59.8 & 2.1 & 0.03 & 52 & 78.8 & 21.2 & 0.0 & 0.00 \\
\hline SMF & 102 & 9.8 & 86.3 & 3.9 & 0.05 & 38 & 39.5 & 60.5 & 0.0 & 0.00 \\
\hline $\mathrm{RF}$ & 25 & 16.0 & 68.0 & 16.0 & 0.24 & 134 & 78.4 & 20.9 & 0.7 & 0.04 \\
\hline
\end{tabular}
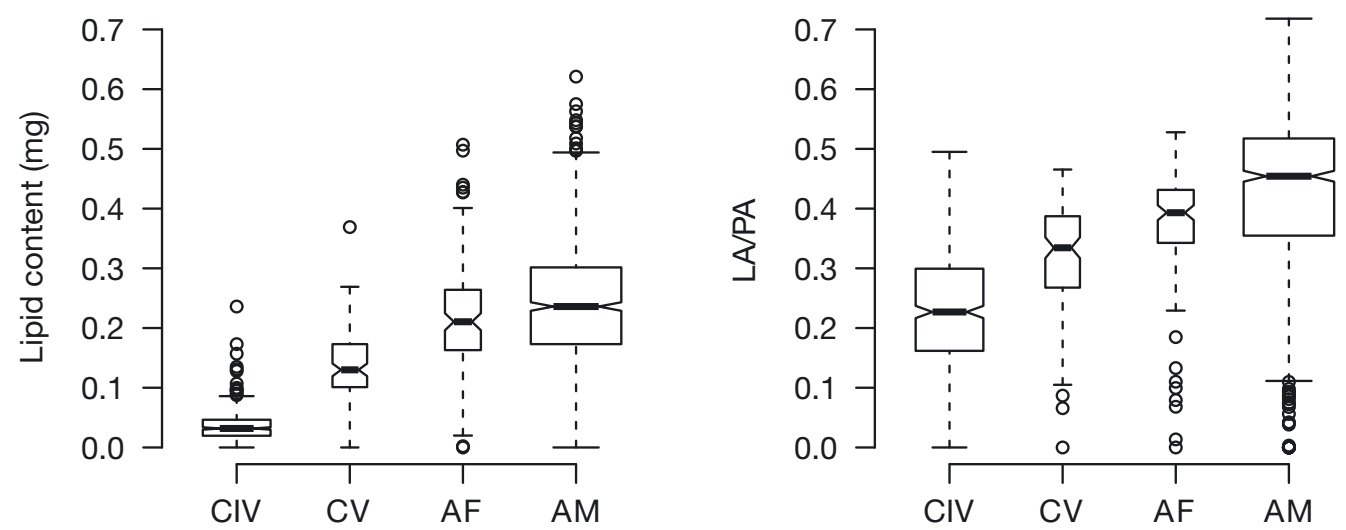

Fig. 7. Box plot of lipid content (mg ind.$^{-1}$ ) and lipid sac area to prosome area ratio (LA/PA) in copepodite stages CIV, CV, adult females (AF), and males (AM) of Calanus glacialis in January 2015 and 2016. Horizontal line: median; bottom and top of the box: $25^{\text {th }}$ and $75^{\text {th }}$ percentiles, respectively; whiskers extend 1.5 times the interquartile range of the sample; values outside this range are marked by circles. The boxes are drawn with widths proportional to the square-roots of the number of observations in the groups. Notches display the variability of the median between samples. If the notches of two boxes do not overlap there is strong evidence that their medians differ at $95 \%$ confidence interval (Chambers et al. 1983)

between stages were significant (Kruskal-Wallis, $\mathrm{p}<$ 0.0001). For lipid content, these differences were due to significant differences between adults and CIV and $C V$, while there was no significant difference in lipid content between AF and AM (Nemenyi post hoc test, $p=0.24)$. However, LA/PA was significantly different among all stages $(p<0.001)$, i.e. AM had a higher LA/PA ratio than AF. Additionally, there was a higher variability of lipid content in AM than in $\mathrm{AF}$ (Fig. 7).

\section{Swimming activity and respiration}

Swimming activity in adult $C$. glacialis varied with sex and collection site (Fig. 8). AF from both sites showed little variation in swimming activity over the duration of the experiment. AM from both sites, however, displayed bouts of elevated swimming activity. For Krossfjorden, these activity bouts were clustered at intervals over the diel cycle, while for RF the activity bouts were uniformly distributed (Rayleigh's test, $\mathrm{p}<0.001$ and $\mathrm{p}=0.211$, respectively). The variance of swimming activity in individuals across time was greater for AM than AF, both in Krossfjorden and RF (rank sum tests, $\mathrm{p}<0.001$ and $\mathrm{p}=0.003$, respectively). This is reflected in bouts of swimming activity up to 381 beam breaks per 30 min in AM from Krossfjorden, and 1118 beam breaks per $30 \mathrm{~min}$ for AM from RF. Overall, activity levels were higher at RF than Krossfjorden (19-25 beam versus 5-7 breaks per $30 \mathrm{~min}$ ). Consistent with activity, weight-specific respiration rates were 2.2-fold higher for AM from $\mathrm{RF}$ than for AF $\left(38.6 \pm 8.6 \mathrm{SE}\right.$ versus $17.5 \pm 4.0 \mathrm{pmol} \mathrm{O}_{2}$ $\left.\mu \mathrm{g}^{-1} \mathrm{DW} \mathrm{h}^{-1}\right)(\mathrm{p}=0.019$, rank sum test).

\section{DISCUSSION}

Adult males of Calanus were present in all 5 Svalbard fjords during our winter studies in January 2015, 2016 and 2017. Given the unimodal length frequency distribution of males, molecular results and additional examination of the morphology of the $5^{\text {th }}$ swimming leg of individuals from RF in 2016, we conclude that only C. glacialis AM were present in the study region 


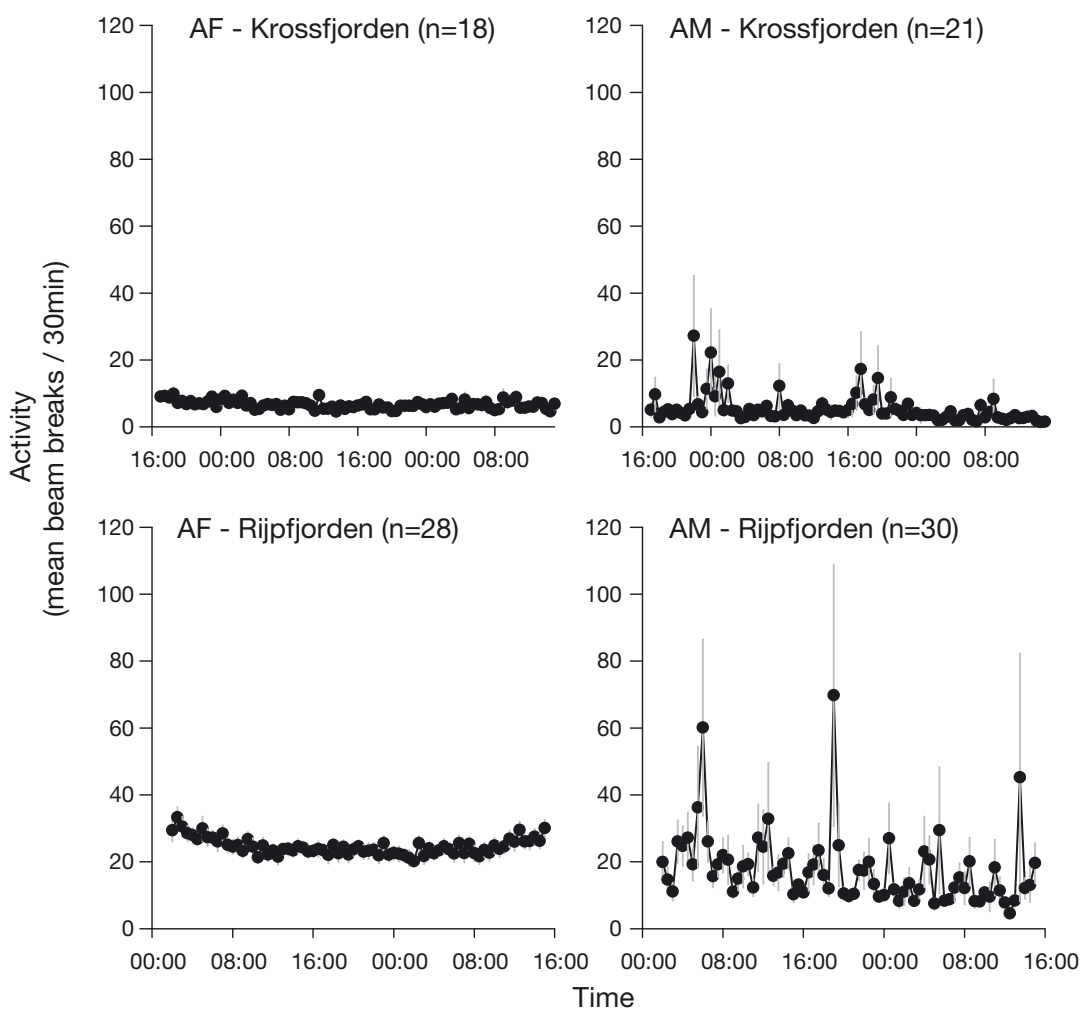

Fig. 8. Swimming activity of Calanus glacialis from Krossfjorden and Rijpfjorden in January 2017. Panels are for adult females (AF) and adult males (AM) from each site. Mean $( \pm \mathrm{SE})$ activity is shown for copepods incubated individually in constant dark conditions over a 2 d period, with activity scored as breaks of infra-red light beam arrays crossing each tube

in January along with a high proportion of AF of the same species. In contrast, $C$. finmarchicus males were absent in January, female abundance was low and late copepodite stages, in particular $\mathrm{CV}$, dominated the overwintering population.

\section{Male size and species identification}

There are very few published data on body size of Calanus AM (Table 5), presumably because of their scarcity in historic sampling campaigns. Prosome lengths for $C$. glacialis AM measured during this study are similar to those previously obtained in Billefjorden, but they are smaller than records from the North Atlantic, Arctic Ocean and the White Sea (Table 5). The size structure of C. finmarchicus AM sampled in May 2017 differed from those identified as C. glacialis in January (Fig. 5, Table 5) confirming that we most likely did not encounter $C$. finmarchicus AM during the January campaigns, and that C. finmarchicus moults later into AM than C. glacialis in Svalbard waters. Similar observations were made in Disko Bay, were AM of C. glacialis were present between September and February with highest proportions in December and January, while C. finmarchicus AM were found from February to May, with maximum proportions between March and May (Madsen et al. 2001, Niehoff et al. 2002). In the Norwegian Sea, a similar timing of occurrence of AM as in Disko Bay was observed by Østvedt (1955). However, observations from lower latitudes indicate that moulting of $C$. finmarchicus to adults may have

Table 5. Overview of available information on size ranges (mm) for adult males of Calanus finmarchicus and C. glacialis

\begin{tabular}{|c|c|c|c|}
\hline Location & $\begin{array}{l}\text { C. finmarchicus } \\
\text { Prosome length }(\mathrm{mm})\end{array}$ & C. glacialis & Reference \\
\hline Svalbard fjords & - & $2.7-4.25\left(3-3.84^{\mathrm{a}}\right)$ & This study \\
\hline $80^{\circ} \mathrm{N}$, western Svalbard & $2.43-3.14^{\mathrm{a}}$ & - & This study \\
\hline $\begin{array}{l}\text { Greenland Sea, Barents Sea, Norwegian } \\
\text { Sea, Central Arctic Ocean }\end{array}$ & $2.34-3.16$ & $3.16-4.1$ & Frost (1971) \\
\hline Disko Bay, Greenland & $2.16-2.92$ & $2.88-3.62$ & Swalethorp et al. (2013) \\
\hline Loch Striven, Clyde area, UK & $2.35-2.67$ & - & Marshall et al. (1934) \\
\hline White Sea & - & $3.5-4.1$ & Kosobokova (1999) \\
\hline \multirow[t]{2}{*}{ Billefjorden, Svalbard } & - & $2.7-3.95$ & Bailey (2010) \\
\hline & Total length (mm) & & \\
\hline North Sea (Isle of Man) & $2.7-3.2$ & - & Gunther (1934) \\
\hline North Sea (L4, UK) & $3.01-3.37$ & - & Russell (1928) \\
\hline aSizes confirmed by molecular analysis & & & \\
\hline
\end{tabular}


already begun in December or January. Adults have been recorded in January and February in all regions from the English Channel to East Greenland (Marshall \& Orr 1955), and Marshall et al. (1934) observed highest abundance of AM in January-February in the North Sea/Scotland, followed by a low constant presence of AM between April and August. Recently, Choquet (2017) observed AM of both C. glacialis and C. finmarchicus co-occurring in January and February in 2 northern Norwegian fjords $\left(67^{\circ} \mathrm{N}\right)$. This suggests that $C$. finmarchicus moults earlier into males at lower latitudes compared to in Svalbard waters, where this species is at the northern border of its distributional range (Conover 1988, Choquet et al. 2017).

Our molecular results from January and May show that there is an overlap in size between AM of C. finmarchicus and C. glacialis, with maximum length of $3.14 \mathrm{~mm}$ of C. finmarchicus AM (Table 5, Fig. 5). A size overlap between these 2 species is common in all copepodite stages and constitutes a challenge when identifying these species (Choquet et al. 2017, 2018). For AM, this problem may be seasonally limited in our study area, since AM of both species did not seem to co-occur in January and May. However, this is likely to differ as soon as C. finmarchicus AM start to appear. From our data on prosome length associated with molecular identification (Fig. 5), we suggest $C$. finmarchicus AM may be correctly identified as individuals smaller than $3 \mathrm{~mm}$, and C. glacialis as individuals larger than $3.2 \mathrm{~mm}$, which is similar to Frost (1971) and Madsen et al. (2001) (Table 5). A larger data set is needed to improve taxonomic resolution within the overlapping size range.

\section{Male abundance}

The presence of AM in the C. glacialis population in January confirms previous observations from Svalbard and other high latitude locations (Fig. 9). Calanus AM have been observed from September to June in the White Sea (Kosobokova 1999), the Canadian Arctic (Wold et al. 2011, Estrada et al. 2012, Darnis \& Fortier 2014) and western Greenland (Madsen et al. 2001, Niehoff et al. 2002), with peak abundance usually observed from November to February (Fig. 9). In Svalbard, Calanus AM have been observed between October and May in Billefjorden (Bailey 2010) and in January in Rijpfjorden (Daase et al. 2014), while Leu et al. (2011) did not observe a single male of Calanus in Rijpfjorden between March and October. Despite Kongsfjorden being one of the most studied fjords in Svalbard, occurrence of Calanus AM has never been reported (e.g. Kwasniewski et al. 2003, 2013, Daase et al. 2013). In our study, we found a high variability in AM abundance among the different fjords and years. Peak abundances observed in Rijpfjorden were comparable to winter abundance previously observed in Billefjorden, while the lower abundance estimates were in the same order of magnitude as estimates from the Canadian Arctic (Fig. 9).

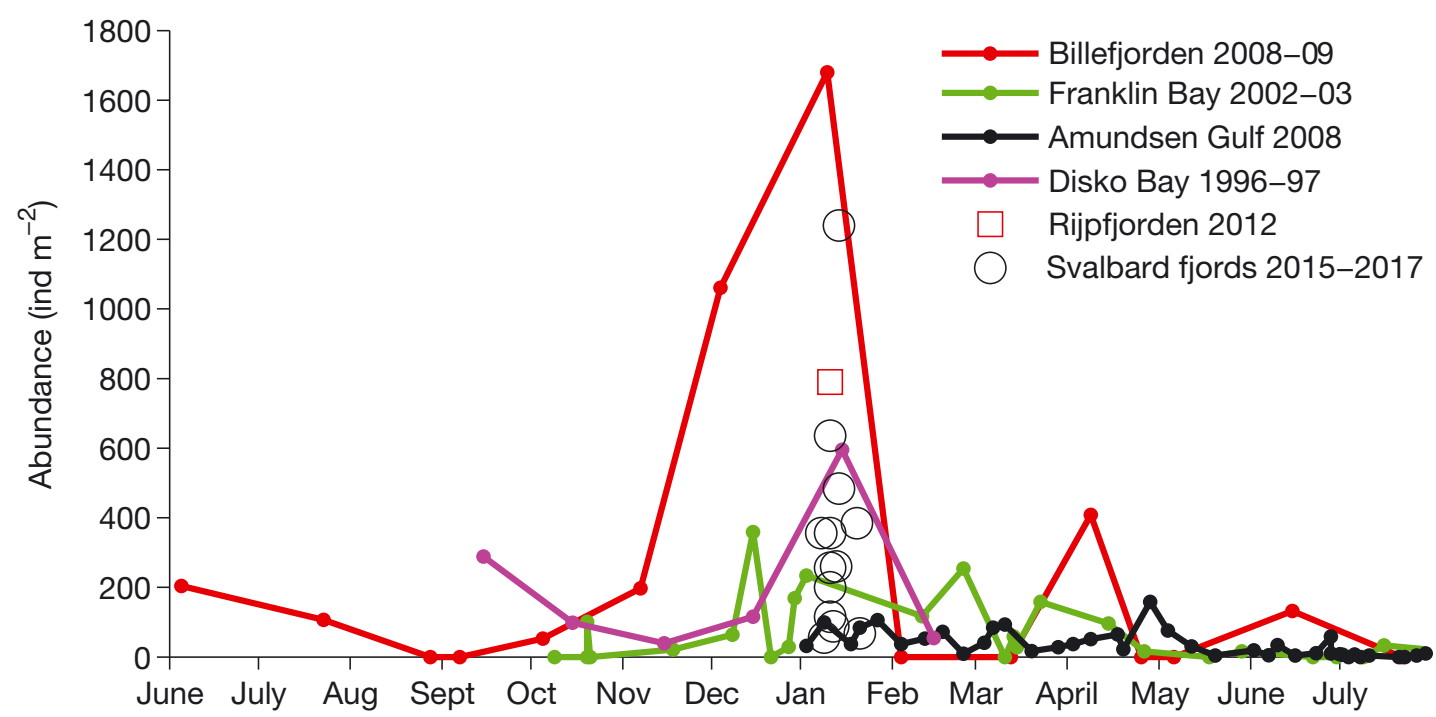

Fig. 9. Seasonal variability of abundance (ind. $\mathrm{m}^{-2}$ ) of Calanus glacialis males across the Arctic: Billefjorden 2008-2009 (Bailey 2010); Franklin Bay 2002-2003 (Fortier \& Darnis 2006); Amundsen Gulf 2007-2008 (Wold et al. 2011); Disko Bay 1996-1997 (Madsen et al. 2001); Rijpfjorden 2012 (Daase et al. 2014); and Svalbard fjords January 2015, 2016 and 2017 (this study). Locations of sampling sites are marked in Fig. 1 


\section{Sex ratios}

Adult sex ratios observed during this study were relatively consistent, varying from $0.3-0.9$ in all years (1-3 females male $\left.{ }^{-1}\right)$. Exception were in RF in 2016, where AM dominated over AF during our study (sex ratio of 1.6, i.e. 1-2 males female ${ }^{-1}$ ), and BF in 2016, where AM were rare (sex ratio of 0.2 , i.e. $4-5$ females male $\left.{ }^{-1}\right)$. Such high proportions of males have not been observed in the study area during any other season (Bailey 2010). In other northern geographical locations, Calanus AF usually substantially outnumber AM in all other seasons (Marshall \& Orr 1955, Conover 1965, Crain \& Miller 2000). For C. glacialis, the only record of seasonal variability in the sex ratio is from the White Sea, where Kosobokova (1999) reported maximum ratio of 0.5-0.6 males:females in October and November, which is comparable to our observations (Table 3 ).

The sex ratios of the pre-adult stage CV were clearly skewed towards females during our study. According to published data, moulting of CVs to AM precedes moulting of CVs to AF (Marshall \& Orr 1955, Kosobokova 1999), and males seem to generally differentiate from the largest CVs (Grigg et al. 1985, 1987, Miller et al. 1991). This is supported by our observations. The prevalence of potential females in CVs indicates that sex differentiation in males and moulting of potential CV males to adults was largely completed by the time of our January sampling period, with the remaining CVs in the overwintering population presumably developing and moulting to AF later in the season.

The high proportion of sexually undifferentiated CVs in BF indicate that the reproductive phenology may have been delayed in BF compared to the other 4 fjords in 2016. The majority of the sexually undifferentiated CVs from BF were C. finmarchicus (Table 4, Fig. S2 in the Supplement). However, $38 \%$ of the CVs in the size range of C. glacialis were also sexually undifferentiated at the time of sampling. Billefjorden also had the lowest percentage of females with spermatophores and the lowest adult sex ratio. Of all the fjords, the C. glacialis population in Billefjorden is the most isolated, since it resides in the inner basin of Billefjorden which experiences reduced water exchange with the outer fjord system and the lowest water temperature (less than $-0.5^{\circ} \mathrm{C}$ ). The delay of maturation and moulting of Calanus CVs in this fjord may therefore be due to low water temperatures compared to the other locations, as development time is known to increase with decreasing temperatures (Campbell et al. 2001).
In our study, $C$. finmarchicus males were absent in January and the abundance of $C$. finmarchicus females was very low while the proportion of sexually undifferentiated $C$. finmarchicus was high (e.g. in Rijpfjorden). This indicates that the time of moulting into adults and mating does not coincide between $C$. finmarchicus and C. glacialis. These elements suggest there is a very low potential for inter-species mating and consequently hybridization is unlikely, which supports results from recent molecular-based studies (Nielsen et al. 2014, Choquet et al. 2017).

\section{Females with spermatophores}

In 2015 and 2016, 3-18\% of Calanus AF had spermatophores attached, indicating that active mating occurred during the studied period. Copulation usually occurs at an early stage in the female's gonad development with a male attaching a spermatophore to the genital segment of a female (Marshall et al. 1934, Marshall \& Orr 1955). Our data support these observations, as we found mainly immature C. glacialis AF bearing spermatophores in January. The spermatophore is retained by Calanus AF only for a short time, while sperm may be stored in spermatheca for a rather long period (i.e. several months), and eggs are presumably fertilized while spawning (Marshall et al. 1934, Marshall \& Orr 1955). The highest proportion of C. glacialis AF with spermatophores occurred in Kongsfjorden in January 2015, where abundance of AF was also highest (Figs. 4 \& 5), as was the relative contribution of AF (28-46\%) and AM (12$25 \%$ ) to the total C. glacialis population. In January 2016, AF and AM contributed only 1-7 and $0.3-10 \%$, respectively, to the total C. glacialis population, as a much higher proportion of overwintering CIVs was observed (Fig. 4). The high proportion of AF and AM in Kongsfjorden in 2015 likely increased the encounter rate between $\mathrm{AM}$ and $\mathrm{AF}_{\text {, }}$ thus leading to a higher percentage of AF bearing spermatophores that year.

Overall, $18 \%$ of females bearing spermatophores fell within the size range defined as $C$. finmarchicus $(<2.95 \mathrm{~mm})$. However, the length frequency distribution of females bearing spermatophores was unimodal, with the smallest individuals being $2.6 \mathrm{~mm}$ (Fig. S1). Given that C. glacialis females may also be of that size (Choquet et al. 2018, Renaud et al. 2018), we find it likely that all females bearing spermatophores were indeed C. glacialis. 


\section{Vertical distribution and metabolism}

It has been proposed that in some calanoid species with extended seasonal migrations AMs concentrate in mesopelagic layers, which ensures high encounter rates and copulation success when AF pass through this layer on their ascent from the overwintering depths (Spiridonov \& Kosobokova 1997). Tsuda \& Miller (1998) suggested that AF and AM of Calanus spp. would benefit from gathering in rather narrow layers of the water column to attract and search for a mate, and that pycnocline or thermohaline stratification would provide favorable conditions for 'painting' pheromone tracks. However, we found that adults of C. glacialis did not concentrate at any particular depths in January. They seemed to avoid the very deepest layer but were otherwise present throughout most of the water column. Such a distribution pattern suggests that both sexes are actively swimming in search of a mate for copulation rather than waiting at a certain depth for a mate to swim by. However, males did display higher swimming activity levels and respiration rates than females, indicating that males engage more than females in actively seeking a mate. This fits with observational (Tsuda \& Miller 1998, Kiørboe \& Bagøien 2005) and theoretical (Kiørboe 2008) studies in other calanoids suggesting that ritualized, directed swimming of males facilitates locating females.

Interestingly, the lipid content of AM was slightly higher than that of AF and much higher than that of the overwintering stages CV and CIV. AM also had significantly higher lipid sac area relative to their body area compared to AF, CVs and CIVs. The relatively high lipid content of AMs observed in January suggests that AMs just recently started to actively mate and thus had not yet depleted their lipid reserves. It may also indicate that AMs may start out with a higher lipid content after moulting to adults compared to AFs, supporting observations from the White Sea that the largest and most lipid-rich CVs are the ones that moult to AMs (Kosobokova 1999). Future studies need to assess the seasonal variability in lipid content between $\mathrm{CVs}$, $\mathrm{AM}$ and $\mathrm{AF}$, especially during the moulting period.

Winter abundance and distribution data for Calanus from the Arctic are still scarce. Our data on vertical distribution of both C. glacialis and C. finmarchicus confirm recent observations from the polar night in Svalbard (Daase et al. 2014, Berge et al. 2015, Błachowiak-Samołyk et al. 2015) that overwintering stages and adults of Calanus are distributed throughout the entire water column in January instead of being concentrated at depth. These observations were made in the same study area as our study (Rijpfjorden, Kongsfjorden) but also in the off-shelf waters north of Svalbard, indicating that such a distribution pattern is not characteristic to fjord populations only. For adults, this may be an indication of a mid-winter ascent from overwintering depth in order to search for a mate. It also suggests an earlier seasonal ascent of the overwintering population from depths than traditionally believed. There is a marked increase in ambient light from the winter solstice to mid-January that may be sufficient enough to function as a visual cue for Calanus to trigger the seasonal ascent (Båtnes et al. 2015, Cohen et al. 2015).

\section{CONCLUSIONS}

Males of Calanus glacialis were much more abundant in mid-winter in Svalbard fjords compared to all other previously studied seasons. The absence of $C$. finmarchicus $\mathrm{AM}$, low abundance of $\mathrm{AF}$ and a high proportion of sexually undifferentiated CVs indicate a distinct reproductive phenology in the 2 species, reducing the likelihood of their interbreeding and hybridization in the study area. The presence of $C$. glacialis AF with spermatophores and elevated swimming activity levels in AM relative to AF revealed that active mate seeking and mating occurs in mid-winter. Furthermore, Calanus populations were distributed throughout the water column and not confined to overwintering depths, corroborating recent studies showing that the polar night is a much more biologically active period than previously assumed (Berge et al. 2015, Ludvigsen et al. 2018). It is apparent that for C. glacialis the polar night is an important reproductive period. We suggest that further studies with increased seasonal and vertical resolution address gaps in our understanding of the life-history strategies of northern Calanus males. Specifically, a better understanding of the timing and energetic costs of the moult to adult, mating and spermatophore production, and the sensitivity of these costs and activities to increased winter temperatures, is now required.

Acknowledgements. We are grateful to Gerald Darnis for providing Calanus male abundance data from Franklin Bay and Amundsen Gulf. We appreciate the help of Captain and crew of RV 'Helmer Hanssen'. This study was funded by the Norwegian Research Council (NRC) through the projects Marine Night (226417), Arctic ABC (244319) and COPPY (227139). K.K. was supported by the Russian Foundation for Basic Research (Project Nos. 15-29-02447 and 16-04-00375), 
the Russian Science Foundation (Project No. 14-50-00095) and performed within the framework of the state assignment of FASO Russia (theme No. 0149-2018-0035). K.S.L. and J.H.C. received additional funding from the MASTS pooling initiative (The Marine Alliance for Science and Technology for Scotland), which is funded by the Scottish Funding Council (grant reference HR09011) and contributing institutions. This study is a contribution to the ARCTOS research network (http://arctos.uit.no).

\section{LITERATURE CITED}

Arnkværn G, Daase M, Eiane K (2005) Dynamics of coexisting Calanus finmarchicus, Calanus glacialis and Calanus hyperboreus populations in a high-Arctic fjord. Polar Biol 28:528-538

Ashjian CJ, Campbell RG, Welch HE, Butler M, Van Keuren D (2003) Annual cycle in abundance, distribution, and size in relation to hydrography of important copepod species in the western Arctic Ocean. Deep Sea Res I 50: 1235-1261

Bailey A (2010) Lipids and diapause in Calanus spp. in a high-Arctic fjord: State-dependent strategies? MSc thesis, University of Tromsø

Båtnes AS, Miljeteig C, Berge J, Greenacre M, Johnsen G (2015) Quantifying the light sensitivity of Calanus spp. during the polar night: Potential for orchestrated migrations conducted by ambient light from the sun, moon, or aurora borealis? Polar Biol 38:51-65

Berge J, Daase M, Renaud Paul E, Ambrose William G Jr and others (2015) Unexpected levels of biological activity during the polar night offer new perspectives on a warming Arctic. Curr Biol 25:2555-2561

* Blachowiak-Samolyk K, Søreide JE, Kwasniewski S, Sundfjord A, Hop H, Falk-Petersen S, Hegseth EN (2008) Hydrodynamic control of mesozooplankton abundance and biomass in northern Svalbard waters $\left(79-8^{\circ} \mathrm{N}\right)$. Deep Sea Res II 55:2210-2224

Błachowiak-Samołyk K, Wiktor JM, Hegseth EN, Wold A, Falk-Petersen S, Kubiszyn AM (2015) Winter tales: the dark side of planktonic life. Polar Biol 38:23-36

Bogorov BG (1939) Sex ratio in marine copepods (on the problem of the evaluation of plankton production). Dokl Akad Nauk SSSR 23:706-709 (in Russian)

Brodskii KA (1967) Calanoida of the far eastern seas and the Polar Basin of the USSR. Keys to the fauna of the USSR. The Zoological Institute of the Academy of Sciences of the USSR No. 35. Israel Program for Scientific Translations, Jerusalem

* Campbell RG, Wagner MM, Teegarden GJ, Boudreau CA, Durbin EG (2001) Growth and development rates of the copepod Calanus finmarchicus reared in the laboratory. Mar Ecol Prog Ser 221:161-183

Chambers JM, Cleveland WS, Kleiner B, Tukey PA (1983) Graphical methods for data analysis. Wadsworth, Belmont, CA

Choquet M (2017) Combining ecological and molecular approaches to redefine the baseline knowledge of the genus Calanus in the North Atlantic and the Arctic Ocean. PhD dissertation, Nord University, Bodø

Choquet M, Hatlebakk M, Dhanasiri AKS, Kosobokova K and others (2017) Genetics redraws pelagic biogeography of Calanus. Biol Lett 13:20170588

Choquet M, Kosobokova K, Kwa niewski S, Hatlebakk M and others (2018) Can morphology reliably distinguish between the copepods Calanus finmarchicus and $C$. glacialis, or is DNA the only way? Limnol Oceanogr Methods 16:237-252

* Cohen JH, Berge J, Moline MA, Sørensen AJ and others (2015) Is ambient light during the high Arctic polar night sufficient to act as a visual cue for zooplankton? PLOS ONE 10:e0126247

* Conover RJ (1965) Notes on the molting cycle, development of sexual characters and sex ratio in Calanus hyperboreus. Crustaceana 8:308-320

* Conover RJ (1988) Comparative life histories in the genera Calanus and Neocalanus in high latitudes of the Northern Hemisphere. Hydrobiologia 167:127-142

Cottier F, Tverberg V, Inall M, Svendsen H, Nilsen F, Griffiths C (2005) Water mass modification in an Arctic fjord through cross-shelf exchange: the seasonal hydrography of Kongsfjorden, Svalbard. J Geophys Res 110:C12005

Crain JA, Miller CB (2000) Detection of sex and sex ratio in Calanus finmarchicus early stage fifth copepodites. ICES J Mar Sci 57:1773-1779

炏Daase M, Eiane K (2007) Mesozooplankton distribution in northern Svalbard waters in relation to hydrography. Polar Biol 30:969-981

* Daase M, Falk-Petersen S, Varpe $\varnothing$, Darnis G and others (2013) Timing of reproductive events in the marine copepod Calanus glacialis: a pan-Arctic perspective. Can J Fish Aquat Sci 70:871-884

* Daase M, Varpe $\varnothing$, Falk-Petersen S (2014) Non-consumptive mortality in copepods: occurrence of Calanus spp. carcasses in the Arctic Ocean during winter. J Plankton Res 36:129-144

* Darnis G, Fortier L (2014) Temperature, food and the seasonal vertical migration of key arctic copepods in the thermally stratified Amundsen Gulf (Beaufort Sea, Arctic Ocean). J Plankton Res 36:1092-1108

* Estrada R, Harvey M, Gosselin M, Starr M, Galbraith PS, Straneo F (2012) Late-summer zooplankton community structure, abundance, and distribution in the Hudson Bay system (Canada) and their relationships with environmental conditions, 2003-2006. Prog Oceanogr 101:121-145

F Falk-Petersen S, Mayzaud P, Kattner G, Sargent J (2009) Lipids and life strategy of Arctic Calanus. Mar Biol Res 5: 18-39

Fortier L, Darnis G (2006) Vertical distribution of Arctic mesozooplankton in Franklin Bay, southern Beaufort Sea, during winter 2003-04. Ocean Biogeographic Information System, Intergovernmental Oceanographic Commission of UNESCO. http://geo.abds.is/ipt/resource? $\mathrm{r}=$ arcod_2007p1

Frost BW (1971) Taxonomic status of Calanus finmarchicus and C. glacialis (Copepoda), with special reference to adult males. J Fish Res Board Can 28:23-30

Frost BW (1974) Calanus marshallae, a new species of calanoid copepod closely allied to sibling species Calanus finmarchicus and Calanus glacialis. Mar Biol 26:77-99

Gabrielsen T, Merkel B, Søreide J, Johansson-Karlsson E and others (2012) Potential misidentifications of two climate indicator species of the marine Arctic ecosystem: Calanus glacialis and C. finmarchicus. Polar Biol 35: 1621-1628

Grigg H, Holmes LJ, Bardwell SJ (1985) Seasonal observation on the biometry and development in copepodite stage V of Calanus finmarchicus from the Firth of Clyde. Mar Biol 88:73-83 
Grigg H, Bardwell SJ, Holmes LJ (1987) Comparative observations on the biometry and development of Calanus finmarchicus and Calanus helgolandicus in copepodite stage $\mathrm{V}$ with comments on other Calanidae. Mar Biol 96: 253-262

Grote U, Pasternak A, Arashkevich E, Halvorsen E, Nikishina A (2015) Thermal response of ingestion and egestion rates in the Arctic copepod Calanus glacialis and possible metabolic consequences in a warming ocean. Polar Biol 38:1025-1033

Gunther ER (1934) Observations on the fatty constituents of marine plankton: I. Biology of the plankton. J Exp Biol 11:173-197

Hirche HJ (1989) Egg-production of the Arctic copepod Calanus glacialis: laboratory experiments. Mar Biol 103: 311-318

Hirche HJ (2013) Long-term experiments on lifespan, reproductive activity and timing of reproduction in the Arctic copepod Calanus hyperboreus. Mar Biol 160: 2469-2481

Hirche HJ, Kosobokova K (2003) Early reproduction and development of dominant calanoid copepods in the sea ice zone of the Barents Sea-need for a change of paradigms? Mar Biol 143:769-781

Hirche HJ, Kosobokova K (2007) Distribution of Calanus finmarchicus in the northern North Atlantic and Arctic Ocean-expatriation and potential colonization. Deep Sea Res II 54:2729-2747

*Hirche HJ, Niehoff B (1996) Reproduction of the Arctic copepod Calanus hyperboreus in the Greenland Seafield and laboratory observations. Polar Biol 16:209-219

Hirche HJ, Kosobokova KN, Gaye-Haake B, Harms I, Meon B, Nothig EM (2006) Structure and function of contemporary food webs on Arctic shelves: a panarctic comparison. The pelagic system of the Kara Sea-communities and components of carbon flow. Prog Oceanogr 71:288-313

Jaschnov WA (1955) Morphology, distribution and systematics of C. finmarchicus s.l. Zool Zh 34:1210-1223

Jaschnov WA (1970) Distribution of Calanus species in the seas of the Northern Hemisphere. Int Rev Gesamten Hydrobiol 55:197-212

* Ji RB, Ashjian CJ, Campbell RG, Chen CS and others (2012) Life history and biogeography of Calanus copepods in the Arctic Ocean: an individual-based modeling study. Prog Oceanogr 96:40-56

Kiørboe T (2008) Optimal swimming strategies in matesearching pelagic copepods. Oecologia 155:179-192

Kiørboe T, Bagøien E (2005) Motility patterns and mate encounter rates in planktonic copepods. Limnol Oceanogr 50:1999-2007

Kjellerup S, Dünweber M, Swalethorp R, Nielsen TG, Møller EF, Markager S, Hansen BW (2012) Effects of a future warmer ocean on the coexisting copepods Calanus finmarchicus and C. glacialis in Disko Bay, western Greenland. Mar Ecol Prog Ser 447:87-108

Kosobokova KN (1998) New data on the life cycle of Calanus glacialis in the White Sea (based on the seasonal observations of the development of its genital system). Okeanologiya 38:387-396

Kosobokova KN (1999) The reproductive cycle and life history of the Arctic copepod Calanus glacialis in the White Sea. Polar Biol 22:254-263

Kosobokova KN, Hirche HJ (2001) Reproduction of Calanus glacialis in the Laptev Sea, Arctic Ocean. Polar Biol 24: 33-43
Kosobokova K, Hirche HJ (2009) Biomass of zooplankton in the eastern Arctic Ocean-a base line study. Prog Oceanogr 82:265-280

* Kwasniewski S, Hop H, Falk-Petersen S, Pedersen G (2003) Distribution of Calanus species in Kongsfjorden, a glacial fjord in Svalbard. J Plankton Res 25:1-20

KKwasniewski S, Gluchowska M, Walkusz W, Karnovsky NJ and others (2012) Interannual changes in zooplankton on the West Spitsbergen Shelf in relation to hydrography and their consequences for the diet of planktivorous seabirds. ICES J Mar Sci 69:890-901

Kwasniewski S, Walkusz W, Cottier FR, Leu E (2013) Mesozooplankton dynamics in relation to food availability during spring and early summer in a high latitude glaciated fjord (Kongsfjorden), with focus on Calanus. J Mar Syst 111-112:83-96

* Leu E, Søreide JE, Hessen DO, Falk-Petersen S, Berge J (2011) Consequences of changing sea-ice cover for primary and secondary producers in the European Arctic shelf seas: timing, quantity, and quality. Prog Oceanogr 90:18-32

*Ludvigsen M, Berge J, Geoffroy M, Cohen JH and others (2018) Use of an autonomous surface vehicle reveals small-scale diel vertical migrations of zooplankton and susceptibility to light pollution under low solar irradiance. Sci Adv 4:eaap9887

* Madsen SD, Nielsen TG, Hansen BW (2001) Annual population development and production by Calanus finmarchicus, C. glacialis and C. hyperboreus in Disko Bay, western Greenland. Mar Biol 139:75-93

Marshall SM, Orr AP (1955) The biology of a marine copepod (Calanus finmarchicus Gunnerus). Springer-Verlag, Berlin

Marshall SM, Nicholls AG, Orr AP (1934) On the biology of Calanus finmarchicus. V. Seasonal distribution, size, weight and chemical composition in Loch Striven in 1933, and their relation to the phytoplankton. J Mar Biol Assoc UK 19:793-828

Mednikov BM (1961) On the sex ratio in deep water Calanoida. Crustaceana 3:105-109

* Miller CB, Cowles TJ, Wiebe PH, Copley NJ, Grigg H (1991) Phenology in Calanus finmarchicus; hypotheses about control mechanisms. Mar Ecol Prog Ser 72:79-91

Niehoff B (2004) The effect of food limitation on gonad development and egg production of the planktonic copepod Calanus finmarchicus. J Exp Mar Biol Ecol 307: 237-259

Niehoff B, Hirche HJ (1996) Oogenesis and gonad maturation in the copepod Calanus finmarchicus and the prediction of egg production from preserved samples. Polar Biol 16:601-612

Niehoff B, Madsen SD, Hansen BW, Nielsen TG (2002) Reproductive cycles of three dominant Calanus species in Disko Bay, West Greenland. Mar Biol 140:567-576

* Nielsen TG, Kjellerup S, Smolina I, Hoarau G, Lindeque P (2014) Live discrimination of Calanus glacialis and $C$. finmarchicus females: Can we trust phenological differences? Mar Biol 161:1299-1306

Nilsen F, Cottier F, Skogseth R, Mattson S (2008) Fjordshelf exchanges controlled by ice and brine production: the interannual variation of Atlantic water in Isfjorden, Svalbard. Cont Shelf Res 28:1838-1853

Østvedt OJ (1955) Zooplankton investigation from weather ship $M$ in the Norwegian Sea, 1948-1949. Hvalrådets Skrifter 40:1-93 
Rasband WS (1997-2009) ImageJ, version 1.41. US National Institutes of Health, Bethesda, MD

Renaud P, Daase M, Banas NS, Gabrielsen TM and others (2018) Pelagic food webs in a changing Arctic: a traitbased perspective suggests a mode of resilience. ICES J Mar Sci 75:1871-1881

Russell FS (1928) The vertical distribution of marine macroplankton. VII. Observations on the behaviour of Calanus finmarchicus. J Mar Biol Assoc UK 15:429-454

Søreide JE, Falk-Petersen S, Hegseth EN, Hop H, Carroll ML, Hobson KA, Blachowiak-Samolyk K (2008) Seasonal feeding strategies of Calanus in the high-Arctic Svalbard region. Deep Sea Res II 55:2225-2244

Søreide JE, Leu E, Berge J, Graeve M, Falk-Petersen S (2010) Timing of blooms, algal food quality and Calanus glacialis reproduction and growth in a changing Arctic. Glob Change Biol 16:3154-3163

Spiridonov VA, Kosobokova KN (1997) Winter ontogenetic migrations and the onset of gonad development in large dominant calanoid copepods in the Weddell Gyre (Antarctica). Mar Ecol Prog Ser 157:233-246

Swalethorp R, Kjellerup S, Nielsen TG (2013) Mesozooplankton size data from Disko Bay, West Greenland, 2008. Pangaea, doi:10.1594/PANGAEA.815151

Tande KS, Hopkins CCE (1981) Ecological investigations of the zooplankton community of Balsfjorden, Northern Norway: the genital system in Calanus finmarchicus and the role of gonad development in overwintering strategy. Mar Biol 63:159-164

Tande KS, Hassel A, Slagstad D (1985) Gonad maturation and possible life cycle strategies in Calanus finmarchicus

Editorial responsibility: Sigrun Jónasdóttir,

Charlottenlund, Denmark and Calanus glacialis in the northwestern part of Barents Sea. In: Gray JS, Christiansen ME (eds) Marine biology of polar regions and effects of stress on marine organisms. Proc $18^{\text {th }}$ European Mar Biol Symp, Oslo. John Wiley and Sons, New York, NY, p 141-155

* Tourangeau S, Runge JA (1991) Reproduction of Calanus glacialis under ice in spring in southeastern Hudson Bay, Canada. Mar Biol 108:227-233

*Tsuda A, Miller CB (1998) Mate-finding behaviour in Calanus marshallae Frost. Philos Trans R Soc Lond B Biol Sci 353:713-720

*Vogedes D, Varpe Ø, Søreide JE, Graeve M, Berge J, FalkPetersen S (2010) Lipid sac area as a proxy for individual lipid content of arctic calanoid copepods. J Plankton Res 32:1471-1477

* Wallace MI, Cottier FR, Berge J, Tarling GA, Griffiths C, Brierley AS (2010) Comparison of zooplankton vertical migration in an ice-free and a seasonally ice-covered Arctic fjord: an insight into the influence of sea ice cover on zooplankton behavior. Limnol Oceanogr 55:831-845

*Wassmann P, Kosobokova KN, Slagstad D, Drinkwater KF and others (2015) The contiguous domains of Arctic Ocean advection: trails of life and death. Prog Oceanogr 139:42-65

* Wilson RJ, Banas NS, Heath MR, Speirs DC (2016) Projected impacts of $21^{\text {st }}$ century climate change on diapause in Calanus finmarchicus. Glob Change Biol 22:3332-3340

* Wold A, Darnis G, Søreide J, Leu E and others (2011) Life strategy and diet of Calanus glacialis during the winter-spring transition in Amundsen Gulf, south-eastern Beaufort Sea. Polar Biol 34:1929-1946

Submitted: January 31, 2018; Accepted: October 15, 2018

Proofs received from author(s): November 22, 2018 